\title{
Brief Reflection on Modern Orthodox Christian Teaching About Social and Economic Issues
}

\author{
Irakli Laitadze \\ Free University of Tbilisi, Tbilisi, Georgia
}

\begin{abstract}
In 2000 Russian Orthodox Church adopted “The Basis of Social Concept of Russian Orthodox Church". Until now the mentioned document remains the only social doctrine officially accepted by any Orthodox Church. The article tries to understand the reasons behind the elaboration of the mentioned doctrine and analyzes its content. The document fails to grasp fully the ongoing processes in the secular society and in the wider world. The present acute social problems, e.g., unemployment, corruption, public finance embezzlement, are either slightly touched upon or avoided. The approaches towards socio-economic issues are general and broad lacking the necessary insights. The meanings of economic activities are archaic. The doctrine does not negate entrepreneurship and wealth but is critical to the purpose and forms of the economic activity. It is quite odd that there is no analysis of secularity which has seriously undermined the position of the church. The doctrine demonstrates the softer approach towards the wealth-creation criticizes the idle poverty and highlights the position of the church as an opponent of income inequality. Conclusion is that despite the shortcomings, "The Basis of Social Concept of Russian Orthodox Church" is a strategic document, an attempt of the Russian Orthodox Church to define its earthly place within the dynamic modern society. The social doctrine is not finished product but rather a process of thought and lays foundation for the further construction of the social doctrine.
\end{abstract}

Keywords: social doctrine, Orthodox Christianity, entrepreneurship

There is not a single coherent and official social teaching in Orthodox Christian realm or any Orthodox Churches have adopted an official social and/or economic doctrine bar the Russian Orthodox Church which until now remains the only church which has formal social teaching. The document named as "The Basis of Social Concept of Russian Orthodox Church" was adopted in 2000. The church has not been defining its social teaching for a long period of time. Probably, the reason behind it was that until 1917 it was one of the structural agencies of the state and thus did not need separate doctrine, and during the soviet repressions the church could not express publicly its social standing. I think that apart from repression, the absence of the social doctrine could be explained by sharing the position of distance that is clearly defined by Greek orthodox theologian, Georgius Manzardis: "The aim of the church is not the competition with or reformation of the world but its transfiguration. For this she does not need own political system, own social teaching or construction of specific social-ethical system" (Mantzaridis, 2000, p. 155).

I think that the positions of those advocating for the non-adoption of social doctrine are based on the following attitudes:

Irakli Laitadze, Ph.D. in Humanities, Dr., Free University of Tbilisi, Tbilisi, Georgia. 
(1) It is not a mission of the church to evaluate the socio-economic systems;

(2) The mission of the church is impossible to be defined by socio-economic parameters;

(3) The adoption of any kind of social or economic doctrine will easily involve the church in discussion with rival doctrines where it would be difficult to defend its position.

But during its centuries-long history, the Russian Orthodox Church has officially formulated its position on social issue and thus has negated the abovementioned position of distancing:

The Manichean despise of the world is not acceptable. Christian's participation in it should be based on the understanding that the world, society, state are the objects of Divine love (...). [Недопустимо манихейское гнушение жизнью окружающего мира. Участие христианина в ней должно основываться на понимании того, что мир, социум, государство являются объектом любви Божией (...). $]^{1}$

Why has the Russian Orthodox Church elaborated and adopted the official social doctrine? To my opinion, there are several reasons:

(1) The Russian Orthodox Church finds itself in unique historic period: She is independent (at least formally) ${ }^{2}$ form the state;

(2) It was considered necessary that believers should have criteria and indicators to deal with the surrounding world;

(3) During soviet period the church was considered as opposing force to the communist regime. Such divergent positioning pushed the church to take on the new mission;

(4) After leaving the social "ghetto" in 90-ies of XX century, the church found itself in front of one of the most atheistic societies of the world. The construction of mutually understandable "language" was needed;

(5) The fear of back-sliding and marginalization in the dynamic present has appeared.

The question arises: what is the objective of the Russian Orthodox Church's social teaching? Within the past simple and static social structures, the church was able to deliver easily its word to an addressee. In modern complex society Church needed additional instrument to penetrate in every social layer, to reach an individual anywhere. The significance of the doctrine should be assessed in long-term perspective.

- The document defines the position of the church which has first time in her history abandoned the traditional state-church relations mode. Namely, church reserves the obligation to contravene the state if she considers it necessary;

- Never the social doctrine such socio-economic topics as private property, globalization, or property inequalities have been formally assessed within church's realm. By considering the abovementioned issues such phenomenon as modern world appears in church's fields of activities;

- Church recognizes people as the source of the state's legitimization and power but does not consider it sacred and receives the state authority as a fait accompli.

With the help of the social doctrine, the church tries to exercise its two main missions: preaching and salvations missions. Without social doctrine, the life of the church can be viewed as completely different realm for the lay persons and thus entails the risk that the church will be alienated from other realms of the life lest not raise the moral of individuals.

The formulations of the concept are prudent, often neutral and are inclined towards generalization which

\footnotetext{
1 Основы социальной концепции Русской Православной Церкви I. 3. https://mospat.ru/ru/documents/social-concepts/.

${ }^{2}$ Конституция Российской Федерации. http://www.constitution.ru/10003000/10003000-3.htm.
} 
leaves open many topics (unemployment, monopoly, etc.). On the top of it, certain parts of the doctrine are contradictory: "It is clear that different chapters of the documents have been written by different authors and resulted to be uncoordinated [очевидно, что разные главы документа писались разными авторами и оказались концептуально не согласованными]” (Novik, 2000, p. 17).

There are no specific indications about the moral parameters of secular activities. General indications used have archaic meanings excluding certain types of business activities. Namely, work means physical labor and does not include such nonmaterial activities as marketing or finances, for the sake of the example. The factors blocking the development as corruption or public finance embezzlement are not even mentioned. Criteria such as effectiveness and profit used for the assessment of business are not employed. According to the social concept the aim of the work is beyond the pure economic activity - it is about the service to neighbor and God. I think that traditional Orthodox Christian social thought has not rationalized entrepreneurship. Orthodox Christianity's (namely of Russian Orthodox Church) modern social teaching has softer approach to business, but even then, it considers a business as a high-risk zone where activities directed towards the profit may corrupt the morale. The wealth itself does not have any moral value (neither negative nor positive). What is important is wealth's social dimension and religious motivation.

The doctrine criticizes existing drastic material inequality. Based on the spirit of social solidarity, the concept demands fair redistribution of the common good and legal restriction of corporations' hyper-profits, but these notions are not elaborated further.

I think there are several positions that are characteristic to the traditional Orthodox Christianity. The partial reflections of these positions can be deducted in modern social doctrine. Namely:

- Entrepreneurship is moral category that is beyond the pure economic realm;

- Self-sufficiency is the desired model of economic activity;

- Moderate production - unlimited (hyper-revenue generating) is not the goal;

- The private property is the function of labor and not of capital;

- The real work is physical labor;

- The work is the virtue and it is one of the forms of ascetism;

- The economic process is directed towards self-sufficiency and not towards profit-maximization;

- Weak vertical hierarchy of the business and existence of communes.

I think that the social doctrine of the Russian Orthodox Church neither accepts nor rejects the material world unconditionally. I think that the Orthodox Christian attitude towards entrepreneurship neither accepts nor rejects this world and is based on peculiar simultaneity of both, on this antinomy. There is the evangelical position: "Love not the world, neither the things that are in the world. If any man loves the world, the love of the Father is not in him" (1 John 2:15). I think that "Love not the world" does not mean "Hate the world" or "Neglect the world". It probably means that an individual should not get attached to the worldly goods unconditionally. Christianity rejects the hierarchy of the values where temporal is above the eternal. Accordingly, the traditional Christian Orthodox approach is not oriented towards economic rationality and effectiveness of the business. Profit and expansion of the commerce have secondary importance. The main objective of the business is beyond economy. Based on this approach the traditional Orthodox Christianity social teaching has not established the spiritual basis for entrepreneur and its attitude towards wealth creation was negatively indifferent. But Orthodox Christianity's (namely Russian Orthodox Church) modern social teaching has changed the above-mentioned approach and now its attitude is positively indifferent towards social 
market economy. The church's light support for market economy is not based on any preference of economic thought. It is based on respect of human freedom and supports such socio-economic framework that can lift the poverty: "We consider that free market can create the structures based on which people can attain the material goods [Мы считаем, что свободный рынок может создать структуры, с помощью которых люди могут добиться благ]" (Novik, 2000, p. 19).

The mentioning of tower of Babel and descendancy of $\mathrm{Caen}^{3}$ makes us think that there is general negative attitude towards economic globalization. Simultaneously, as per doctrine, it is neither possible nor desirable to hide from the globalization but together with undeniable positive economic outcomes Church notices and criticizes the growing material inequality.

I think that the position of the Russian Orthodox Church is integral towards property ownership and labor. The doctrine urges the believers to concentrate on the spiritual side of mentioned issues. Overall, the attitude of the Russian Orthodox Church is less rigid. The wealth is not considered anymore as unconditional barrier on the way of salvation and inaction in the poverty is criticized. The wealth is not a fault but is in the vicinity of sin thus it is within the high-risk zone. The material wealth is viewed as a value-neutral and in principle, such an attitude is a novelty. Via the prism of its doctrine, the Patriarchate of Moscow sees the world not as it is but as it must be-Christian world. Such standing entails the difficulty on elaboration of social doctrine vis-à-vis secular society. For the moment, the mentioned social doctrine is not fully equipped with relevant terms and methodology. I think that present confrontation of free and social market economies presents dilemma of choice which is alien to the traditional church. The church is neutral to any economic doctrine. Simultaneously, the church has its social ideal which is impossible to realize. The church is aware of this and the mentioned ideal performs the role of measure and orientation.

"The Basis of Social Concept of the Russian Orthodox Church" is contradictory document full of unanswered issues. The positions of the document are often too abstract with concrete proposals. Can this social doctrine create the basis for understanding the ongoing societal processes? I think that it cannot yet. Is it equipped with the methods for the problems' resolution? I think it is not. The existing social teaching is more than process than fait accompli. Still, notwithstanding many deficiencies, the present social doctrine is a big step forward. First in the long history of the Russian Orthodox Church, such concepts as free market and economic globalization enter in its vocabulary. "The Basis of Social Concept of the Russian Orthodox Church" is the strategic document that indicates the turn of the church to a market economy. This document creates the fundament for further elaboration of the teaching on social and economic issues.

I think that Nikolay Berdyaev has formulated the quintessential idea of the present social doctrine many years before its adoption:

The problem of the bread for me is materialistic issue but the bread for my neighbor, for all people is spiritual, religious issue. [Вопрос о хлебе для меня есть вопрос материальный, но вопрос о хлебе для моих ближных, для всех людей, есть духовный, религиозный вопрос.] (Berdyaev, 2003, с. 251)

\section{References}

Ananyev, Е. (2010). Социальная конщепция Русской Православной Церкви: Ответы церкви на вызови времени (Тhе Sосіаl Concept of Russian Orthodox Church: The response to the challenges of modernity). Moscow, Russian Way. Arnold, G. (2005). Corporate finance. NJ, USA: Prentice Hall.

${ }^{3}$ Основы социальной концепции, op.cit., VI. 3. 
Berdyaev, N. (2003). Истоки и смысль Русского коммунизма (The foundation and idea of Russian communism). Moscow: BC. Blank, R., \& McGurn, W. (2004). Is the market moral? Washington, D.C.: Brookings Institution Press.

Braslavsky, P. (n.d.). Современный социально-экономический этос Русской Православной Церкви: перспективы и границы толерантности (Modern socio-economic ethos of Russian Orthodox Church: perspectives and limits of tolerance). Retrieved from http://kansas.ru/pb/paper/roc.pdf

Bulgakov, S. (2009). Философия хозяйства (The philosophy of Economy). Moscow: Institute of Russian civilization.

Ekzemplriasky, V. (2013). Учение древней Церкви о собственности и милостыне (The teaching of ancient Church about the property and charity). Krasnodar: Text.

Kirill, Bishop of Smolensk and Kalinigrad. (n.d.). Доклад на заседании Отделения экономики РАН 4 октября 2001 г (Report for economic section of Russian Academy of Science, on 4th of October, 2001). Retrieved from http://www.mospat.ru/text/news/id/5784.htm

Koval, T. (n.d.). Христианская этика труда в сравнительной перспективе (The Christian ethics of work in comparative perspective). Retrieved from http://www.sobor.ru/doctrina/2Shvedov_ru.asp

Mantzaridis, G. (2000). The baselines of Christian ethics. NJ, USA: Prentice Hall.

Novik, V. (2000). Об основах социальной концепций Русской Православной Церкви (About the Basis of Social Concept of Russian Orthodox Church). Sobornost, 3, 17-38.

Payne, D. (2014). Eastern Orthodoxy's theology of economics. Oxford: Oxford University Press.

Sombart, W. (2005). Буржуа: К истории духовного развития современного экономического человека (Bоurgeois: History of spiritual development of modern economic man). Saint-Petersburg: Vladmiri Dal.

The Basis of Social Concept of Russian Orthodox Church ("Round-table discussion) (Основы социальной концепции Русской Православной Церкви (“Круглый стол”)). Retrieved from http://ecsocman.hse.ru/data/607/596/1231/015Osnovy.pdf

The Basis of Social Concept of Russian Orthodox Church (Основы социальной концепций Русской Православной Церкви) (ОСК РПЦ). (n.d.). Retrieved from https://mospat.ru/ru/documents/social-concepts/

Weber, M. (2012). The protestant ethic and the spirit of capitalism. Renaissance Classics. 